\title{
Keanekaragaman katak dan kodok (Amphibia: Anura) di Suaka Margasatwa Paliyan, Gunungkidul, Yogyakarta
}

\author{
Frog and toad diversity (Amphibia: Anura) \\ in Paliyan Wildlife Sanctuary, Gunungkidul, Yogyakarta \\ Donan Satria Yudha ${ }^{1, *}$, Rury Eprilurahman ${ }^{1}$, Hastin Ambar Asti ${ }^{2}$, Herofi Azhar ${ }^{2}$, \\ Nurrochmah Wisudhaningrum $^{3}$, Puji Lestari ${ }^{3}$, Siti Markhamah $^{3}$, Imam Sujadi ${ }^{3}$ \\ ${ }^{1}$ Laboratorium Sistematika Hewan, Fakultas Biologi Universitas Gadjah Mada, Yogyakarta 55281 \\ ${ }^{2}$ Kelompok Studi Herpetologi, Fakultas Biologi Universitas Gadjah Mada, Yogyakarta 55281 \\ ${ }^{3}$ Balai Konservasi Sumber Daya Alam, Yogyakarta 55514
}

Email:donan_satria@ugm.ac.id

Diterima 8 April 2019; Disetujui 25 November 2019

\section{INTISARI}

Katak dan kodok biasa dijumpai oleh manusia. Katak dan kodok dapat menjadi salah satu bioindikator baik buruknya suatu lingkungan. Suaka Margasatwa (SM) Paliyan terletak di Kawasan karst Gunungkidul, Provinsi Daerah Istimewa Yogyakarta. Kawasan karst memiliki tipe habitat endapan tanah tipis, dengan batuan dasar berupa batu kapur tersebut berfungsi sebagai tempat melindungi satwa liar dan belum dikembangkan sebagai kawasan wisata. Keanekaragaman jenis katak dan kodok di dalam Kawasan Suaka Margasatwa Paliyan, Gunungkidul belum terdata secara menyeluruh. Penelitian ini bertujuan untuk mengetahui keanekaragaman jenis katak dan kodok yang habitatnya di area karst di dalam area konservasi yaitu Kawasan Suaka Margasatwa Paliyan. Selama sampling, total dijumpai 9 jenis katak dan kodok, yaitu: Duttaphrynus melanostictus, Ingerophrynus biporcatus, Fejervarya limnocharis, Kaloula baleata, Occidozyga lima, Occidozyga sumatrana, Microhyla orientalis, Microhyla palmipes dan Polypedates leucomystax. Keanekaragaman Katak dan Kodok di SM Paliyan, berdasarkan Indeks Shanon-Wiener (H'): 1,43 yang artinya keanekaragamannya sedang. Wilayah SM Paliyan cocok bagi habitat katak dan kodok karena memiliki lokasi dengan hutan yang rindang, semak yang lebat, sungai-sungai dan telaga, serta area yang jarang dijadikan aktivitas manusia.

Kata kunci : katak, kodok, keanekaragaman, Paliyan, Suaka Margasatwa

\begin{abstract}
Frogs and toads commonly found by human. Frogs and toads could become a bio-indicator of an environment. Paliyan Wildlife Sanctuary is a forest area which posses several animal to protect and it's located in Gunungkidul Regency, Province of DIY. The diversity of frogs and toads in this wildlife sanctuary is not yet recorded and published. The aim of this research is to understand the diversity of frogs and toads in the area of Paliyan Wildlife Sanctuary. The results there were 9 species of frogs and toads, i.e., Duttaphrynus melanostictus, Ingerophrynus biporcatus, Fejervarya limnocharis, Kaloula baleata, Occidozyga lima, Occidozyga sumatrana, Microhyla orientalis, Microhyla palmipes and Polypedates leucomystax. The diversity of frogs and toads in the wildlife sanctuary is moderate according to the Shannon-Wiener Index with value: 1,43. Area of Paliyan Wildlife Sanctuary is a suitable habitat for frogs and toads due to its location with dense forest, bushes, rivers, lakes and pools as well as least human activities.
\end{abstract}

Keywords: diversity, frogs, Paliyan, toads, wildlife sanctuary 


\section{PENDAHULUAN}

Katak dan kodok adalah amfibi yang secara taksonomi, masuk ke dalam kelas Amphibia, ordo Anura. Katak dan kodok biasa dijumpai oleh manusia. Katak dan kodok dapat menjadi salah satu bioindikator baik buruknya suatu lingkungan. Secara alami katak dan kodok menyukai habitat lembab, bersemak, terdapat genangan air dan berkanopi. Kulit katak tipis dan berlendir, menjadikan katak tidak mampu hidup di tempat panas dan kering, karena suhu yang panas dan kering akan menyebabkan dehidrasi hingga menyebabkan kematian. Di Jawa terutama di wilayah Daerah Istimewa Yogyakarta terdapat enam familia anggota Ordo Anura yaitu: Bufonidae, Ranidae, Dicroglossidae, Rhacophoridae, Microhylidae dan Megophryidae (Zug, 1993; Pough et al., 1998; Iskandar, 1998; Eprilurahman dan Kusuma, 2011; Yudha et al,, 2013; Yudha et al. 2014).

Suaka Margasatwa (SM) Paliyan memiliki lokasi Kecamatan Paliyan dan Kecamatan Saptosari, Kabupaten Gunung Kidul dengan luas total 434,60 hektar. Topografi utama wilayah SM berupa perbukitan karst dengan lapisan tanah yang tipis, memiliki kelerengan di atas $40 \%$ dan berada pada ketinggian $100-300 \mathrm{~m}$ dpl. Suaka Margasatwa Paliyan pada awalnya merupakan hutan produksi yang telah dialih fungsikan menjadi hutan lindung sejak tahun 2000. Kawasan SM Paliyan, Gunungkidul, berada di wilayah kewenangan Kantor Seksi Konservasi Wilayah (SKW) II Balai Konservasi Sumber Daya Alam (BKSDA) Bantul.

Keanekaragaman jenis amfibi terutama katak dan kodok di dalam Kawasan Suaka Margasatwa Paliyan, Gunungkidul belum terdata dengan baik, lengkap dan menyeluruh. Penelitian mengenai keanekaragaman amfibi telah dilakukan oleh Ramadhani (2015) di musim kemarau, sehingga datanya kurang maksimal. Data tersebut dianggap kurang maksimal karena katak dan kodok banyak keluar dari persembunyian sehingga tampak melimpah di musim penghujan daripada musim kemarau. Diperlukan pendataan ulang dengan lebih baik, lengkap dan menyeluruh sebagai referensi ilmiah terutama bagi anggota amfibi khususnya anura (katak dan kodok). Penelitian ini bertujuan untuk mengetahui keanekaragaman jenis katak dan kodok yang terdapat di dalam Kawasan Suaka Margasatwa Paliyan, Propinsi Daerah Istimewa Yogyakarta (DIY). Keanekaragaman tersebut berguna untuk memberikan informasi lebih lengkap dan database yang dapat dijadikan acuan bagi penelitian selanjutnya.

\section{MATERI DAN METODE}

Spesimen yang dipelajari adalah semua jenis amfibi anggota ordo Anura yang habitatnya berada di dalam alam Kawasan Suaka Margasatwa Paliyan, Kabupaten Gunungkidul, Propinsi DIY. Alat dan bahan yang digunakan dalam penelitian ini adalah: Global Positioning System (GPS), kamera, kantong spesimen, jaring, dan headlamps.

Penelitian dilakukan selama enam hari dari tanggal 5 sampai dengan 10 Maret 2018. Lokasi penelitian terletak di dalam Kawasan Suaka Margasatwa Paliyan, Gunungkidul. Metode yang digunakan metode Visual Encounter Survey (VES) yang dikombinasikan dengan metode patch, kuadrat dan time search. Pengambilan data keanekaragaman katak dan kodok dilakukan di keseluruhan 6 (enam) petak/stasiun kawasan SM Paliyan, yaitu Petak 136, 137, 138, 139, 140 dan 141 (Gambar 1). Petak 136 mewakili area dengan aktivitas manusia tinggi, karena dekat dengan jalan raya dan kantor utama Resort Paliyan. Petak 137 mewakili area dengan aktivitas manusia rendah, berupa padang rumput dan adanya genangan air berupa danau dengan vegetasi riparian, yang merupakan habitat potensial bagi keberadaan katak dan kodok. Petak 138 dan 139 merupakan area hutan lebat dengan pepohonan tinggi dan kanopi rapat, tetapi tanpa genangan air. Petak 140 merupakan area hutan terbuka, dengan beberapa aktivitas manusia di sekitar area. Petak 141 merupakan area terbuka dengan danau kecil di dalamnya, serta banyak semak maupun herba di sekeliling danau.

Titik sampling ditentukan menggunakan metode patch, yaitu berdasarkan potensi kehadiran herpetofauna, potensi kehadiran dapat berupa: kemungkinan habitat sebagai tempat tinggal, feeding area, dan nesting area. Kemudian pada 
setiap patch yang telah ditentukan, diterapkan metode VES, kuadrat dan time search. Pengambilan data pada setiap titik sampling dilakukan dalam dua waktu yang berbeda dalam satu hari, yaitu sampling pagi-siang dan sampling malam (Jaeger, 1994, Jaeger and Inger, 1994; Crump and Scott Jr, 1994; Heyer et al, 1994; Karns, 1986).

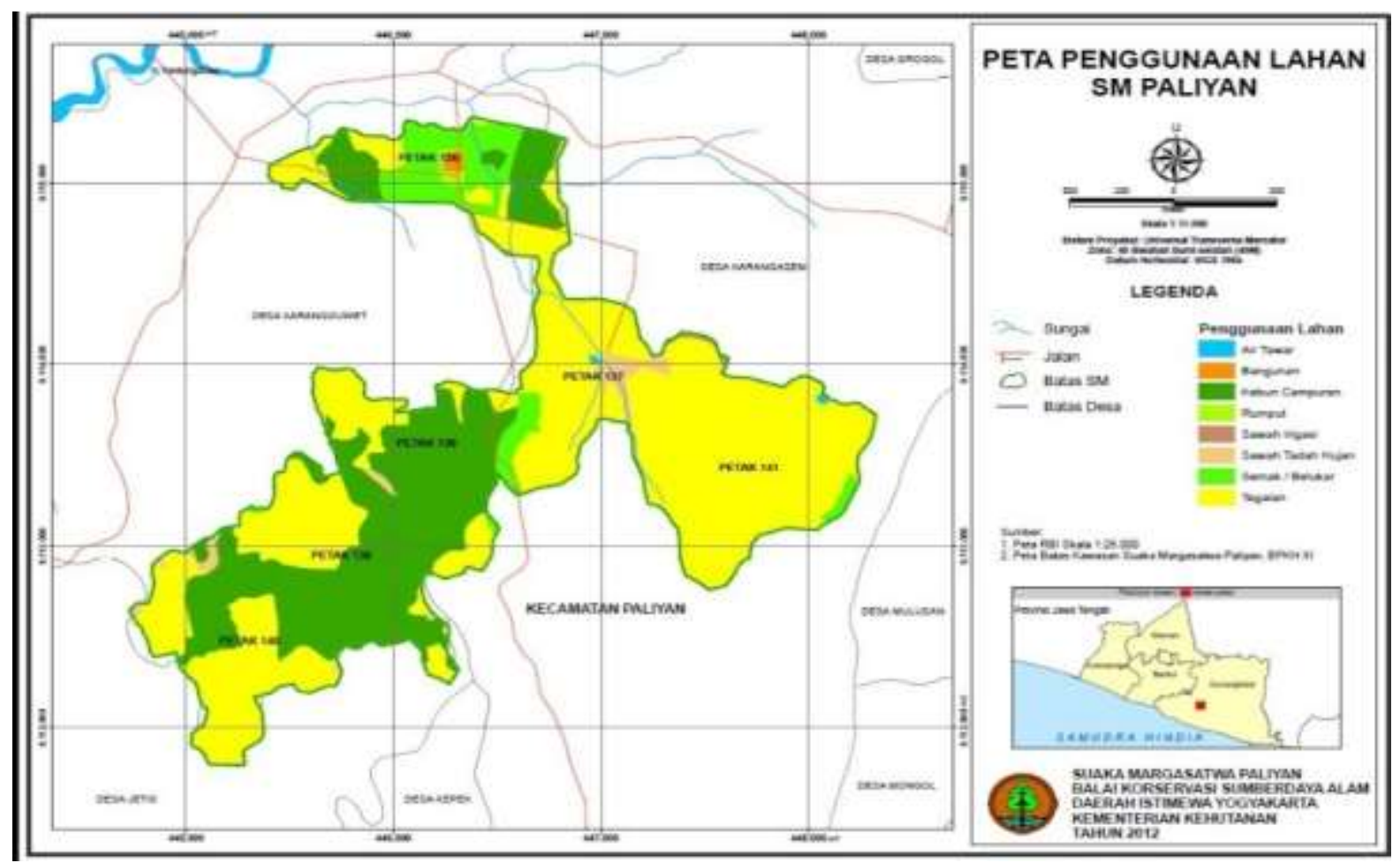

Gambar 1. Peta penggunaan lahan dan pembagian petak di Suaka Margasatwa Paliyan, Gunungkidul (Sumber: Suaka Margasatwa Paliyan, 2012).

Semua spesimen katak dan kodok (kelas Amphibia, ordo Anura) direkam koordinat ditemukannya, didokumentasi, ditangkap, dibawa ke basecamp untuk diidentifikasi. Keesokan harinya spesimen dilepaskan kembali ke habitatnya. Identifikasi anura berdasar Iskandar (1998), Kurniati (2003) dan van Kampen (1923).

Data yang didapatkan kemudian dianalisis menggunakan indeks keanekaragaman ShannonWiener (Türkmen and Kazanci, 2010; Bibi and Ali, 2013; Suprapto, 2014) dan frekuensi keterdapatan jenis (Misra, 1968 dalam Ismawan et al, 2015).

\section{Frekuensi keterdapatan Jenis Reptil dan Amfibi (Herpetofauna)}

Perhitungan frekuensi keterdapatan (Fi) menggunakan persamaan yang diadopsi dari (Misra, 1968 dalam Ismawan et al., 2015) yaitu:
Indeks keanekaragaman berdasarkan ShannonWiener:

$$
\mathrm{H}^{\prime}=-\Sigma \mathrm{Pi} \text { Ln Pi }
$$

H' = Indeks Keanekaragaman Shannon-Wiener

$\mathrm{Pi}=$ Proporsi jenis ke-i (ni/Ni)

ni $=$ Jumlah individu spesies

$\mathrm{Ni}=$ Jumlah total individu

Jika :

$0<\mathrm{H}^{\prime}<1 \quad=$ keanekaragaman sangat rendah

$1<\mathrm{H}^{\prime}<1,5=$ keanekaragaman rendah

$1,5<\mathrm{H}^{\prime}<2,0=$ keanekaragaman sedang

$\mathrm{H}^{\prime}>2.0=$ keanekaragaman

$$
F i=\frac{\text { Jumlah stasiun spesies ke-iteramati }}{\text { jumlah semua stasiun pengamatan }} \times 100 \%
$$




\section{HASIL}

Selama sampling, total dijumpai 9 jenis katak dan kodok, yaitu: Duttaphrynus melanostictus (kodok buduk, kodok puru), Ingerophrynus biporcatus (kodok puru hutan), Fejervarya limnocharis (katak tegalan), Kaloula baleata (belentuk), Occidozyga lima (bancet hijau), Occidozyga sumatrana (bancet rawa Sumatera),
Microhyla orientalis (percil), Microhyla palmipes (percil berselaput), dan Polypedates leucomystax (katak pohon bergaris) (Tabel 1). Ingerophrynus biporcatus (kodok puru hutan) adalah jenis kodok yang paling melimpah, sedangkan Fejervarya limnocharis (katak tegalan) adalah jenis katak yang paling melimpah. Perawakan kedua jenis tersebut dapat dilihat pada Gambar 2.

Tabel 1. Keanekaragaman katak dan kodok di Kawasan SM Paliyan tahun 2018.

\begin{tabular}{cclllc}
\hline No. & Kelas & Ordo & \multicolumn{1}{c}{ Familia } & \multicolumn{1}{c}{ Spesies } & $\begin{array}{c}\text { Cacah } \\
\text { Individu }\end{array}$ \\
\hline 1 & Amphibia & Anura & Bufonidae & $\begin{array}{l}\text { Duttaphrynus melanostictus } \\
\text { Ingerophrynus biporcatus }\end{array}$ & 9 \\
2 & & & Bufonidae & Fejervarya limnocharis & 39 \\
3 & & Dicroglossidae & Kaloula baleata & 5 \\
4 & & Dicroglossidae & Occidozyga lima & 2 \\
5 & & Dicroglossidae & Occidozyga sumatrana & 8 \\
6 & & Dicroglossidae & Microhyla orientalis & 2 \\
7 & & Microhylidae & Microhyla palmipes & 3 \\
8 & & Microhylidae & Polypedates leucomystax & 8 \\
9 & & & Rhacophoridae & & \\
\hline
\end{tabular}

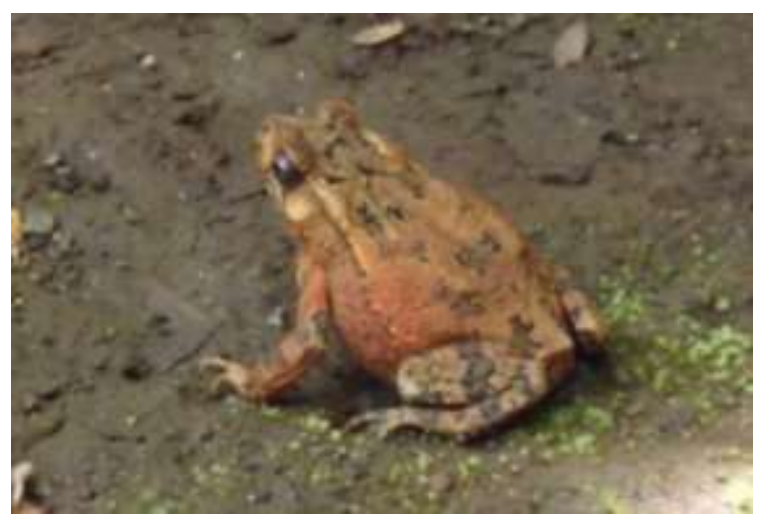

(a)

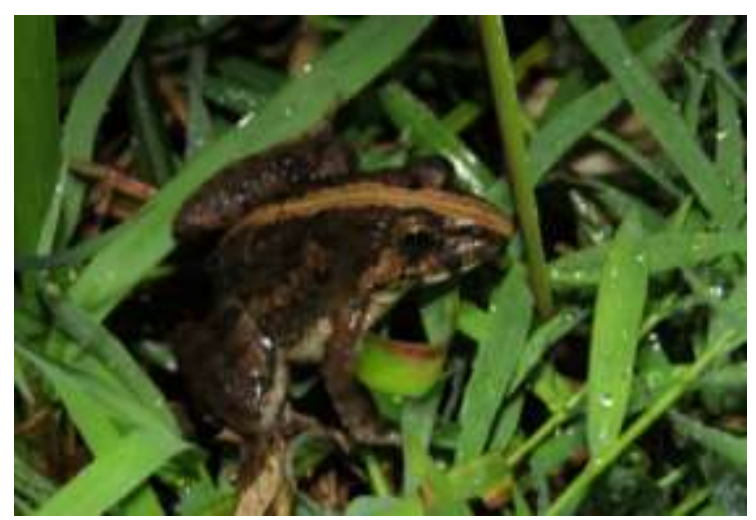

(b)

Gambar 2. Jenis kodok dan katak yang paling melimpah di SM Paliyan (a) kodok puru hutan (Ingerophrynus biporcatus); dan (b) katak tegalan (Fejervarya limnocharis).

Berdasarkan indeks keanekaragaman Shannonwiener (H'), untuk kelompok amfibi diperoleh nilai $\mathrm{H}^{\prime}=1.43$. Maka dapat diartikan bahwa keanekaragaman jenis amfibi di SM Paliyan "sedang", artinya tidak banyak spesies dan juga tidak sedikit spesies amfibi terutama anura yang menghuni SM Paliyan (Tabel 2). 
Tabel 2. Jumlah individu katak dan kodok yang dijumpai serta Nilai Indeks Diversitas Shannon-Wiener katak \& kodok di Kawasan SM Paliyan.

\begin{tabular}{|c|l|l|l|l|l|l|l|l|}
\hline \multirow{2}{*}{ Lokasi } & \multicolumn{5}{|c|}{ Petak } & \multirow{2}{*}{$\begin{array}{c}\text { Total } \\
\text { individu }\end{array}$} & $\begin{array}{c}\text { Nilai Indeks Diversitas } \\
\text { Shannon-Wiener (H') }\end{array}$ \\
\cline { 2 - 9 } & $\mathbf{1 3 6}$ & $\mathbf{1 3 7}$ & $\mathbf{1 3 8}$ & $\mathbf{1 3 9}$ & $\mathbf{1 4 0}$ & $\mathbf{1 4 1}$ & & \\
\hline Jumlah individu & 5 & 7 & 3 & 6 & 3 & 3 & 27 & 1.43 \\
\hline
\end{tabular}

Berdasarkan nilai frekuensi keterdapatan spesies katak dan kodok di SM Paliyan pada semua enam stasiun (Tabel 3), maka dapat dijelaskan bahwa: spesies katak tegalan (Fejervarya limnocharis) dan katak pohon bergaris (Polypedates leucomystax) paling banyak terdapat di Kawasan di SM Paliyan.

Tabel 3. Nilai Frekuensi Keterdapatan (Fi) Spesies Amfibi yang dijumpai pada enam petak (stasiun pengamatan) di SM Paliyan

\begin{tabular}{|c|c|c|c|c|c|c|}
\hline No. & Kelas & Ordo & Familia & Spesies & $\begin{array}{c}\text { Petak } \\
\text { Teramati }\end{array}$ & $\mathbf{F i}$ \\
\hline 1 & Amphibia & Anura & Bufonidae & Duttaphrynus melanostictus & 3 & $50 \%$ \\
\hline 2 & & & Bufonidae & Ingerophrynus biporcatus & 3 & $50 \%$ \\
\hline 3 & & & Dicroglossidae & Fejervarya limnocharis & 6 & $100 \%$ \\
\hline 4 & & & Dicroglossidae & Kaloula baleata & 3 & $50 \%$ \\
\hline 5 & & & Dicroglossidae & Occidozyga lima & 1 & $16.70 \%$ \\
\hline 6 & & & Dicroglossidae & Occidozyga sumatrana & 3 & $50 \%$ \\
\hline 7 & & & Microhylidae & Microhyla orientalis & 1 & $16.70 \%$ \\
\hline 8 & & & Microhylidae & Microhyla palmipes & 2 & $33.30 \%$ \\
\hline 9 & & & Rhacophoridae & Polypedates leucomystax & 5 & $83.30 \%$ \\
\hline
\end{tabular}

\section{PEMBAHASAN}

Dijumpainya 9 jenis katak dan kodok tersebut, mengindikasikan bahwa kondisi kawasan SM Paliyan memiliki kondisi yang dapat digunakan sebagai habitat amfibi. Goin et al, (1978) menyebutkan bahwa amfibi mampu bertahan hidup pada kisaran suhu $3-41^{\circ} \mathrm{C}$. Kisaran tersebut sangat penting bagi amfibi dikarenakan fisiologi amfibi sangat tergantung pada suhu dan air. Rentang suhu di wilayah SM Paliyan untuk suhu udara adalah 24 - $31^{\circ} \mathrm{C}$ sedangkan suhu air berkisar antara 23 $30^{\circ} \mathrm{C}$.

Duttaphrynus melanostictus (kodok buduk) dan Ingerophrynus biporcatus (kodok puru hutan) dijumpai pada tanah kering maupun lembab. Cacah individu Ingerophrynus biporcatus berjumlah 76 individu, menandakan bahwa kawasan tersebut cocok sebagai habitatnya. Kodok puru hutan menyukai habitat hutan primer dan sekunder dengan sedikit atau tanpa aktivitas manusia. Duttaphrynus melanostictus dijumpai 9 individu, hal tersebut menandakan habitat di SM Paliyan kurang begitu cocok untuk Duttaphrynus melanostictus. Kodok buduk ini umumnya dijumpai pada habitat dengan frekuensi aktivitas manusia yang tinggi, dan hampir tidak pernah dijumpai di hutan.

Fejervarya limnocharis, Kaloula baleata, Occidozyga lima, Occidozyga sumatrana dijumpai pada kolam-kolam dan danau di dalam kawasan. Polypedates leucomystax (katak pohon bergaris) merupakan katak pohon dengan cacah individu sebanyak 8 individu, hal tersebut menandakan bahwa beberapa jenis pohon merupakan habitat yang sesuai untuk katak pohon tersebut.

Tumbuhan di area SM Paliyan berupa pepohonan, semak dan herba. Pepohonan, semak dan herba di daerah lembab dan dekat dengan genangan air, merupakan habitat yang disukai oleh katak pohon bergaris. Katak pohon bergaris dijumpai saat sampling malam hari, terutama saat 
sedang beristirahat di batang maupun daun pepohonan dan semak. Semua katak pohon bergaris yang dijumpai saat usia dewasa.

Adanya berbagai jenis anura dengan tipe habitat yang berbeda tersebut, menandakan bahwa di SM Paliyan memiliki kondisi yang sesuai bagi habitat anura meskipun wilayahnya berupa kawasan karst. Indikasi bahwa SM Paliyan merupakan habitat sesuai bagi anura adalah: adanya sumber air, kondisi lingkungan yang lembab pada beberapa area, terdapat banyak pepohonan dan semak, dijumpai 9 jenis anura dengan 2 jenis anura memiliki cacah individu di atas 20 individu. Variasi relung habitat yang berbeda menunjukkan keanekaragaman yang spesifik sesuai sifat hidup masing-masing jenis. Variasi relung yang ada berupa: area terbuka dengan semak dan rumput, area danau dengan vegetasi riparian, area hutan dengan pepohonan tinggi dan kanopi lebat.

Berdasarkan Tabel 3, katak tegalan (Fejervarya limnocharis) frekuensi keterdapatannya $100 \%$ berarti katak ini berada di enam petak kawasan, dan katak pohon bergaris (Polypedates leucomystax) $83,3 \%$ berarti katak ini berada di lima petak kawasan, yaitu petak 136, 137, 138, 139 dan 140. Katak tegalan dijumpai di enam petak, menandakan bahwa wilayah tersebut merupakan habitat dengan sumber air yang cukup. Katak tegalan biasanya ditemukan tidak jauh dari sumber air seperti Telogo Ngringin dan Telogo Ngasinan. Katak tersebut biasanya berada di semak-semak di sekitar sumber air atau telaga dan beraktivitas pada sore hingga malam hari. Katak pohon bergaris merupakan jenis yang umum dijumpai di wilayah pemukiman penduduk. Jenis tersebut mampu beradaptasi di beberapa lokasi dengan kelembaban yang sesuai. Aktivitas utama biasanya di pepohonan dan vegetasi di sekitar sumber air baik sumber air alami maupun buatan.

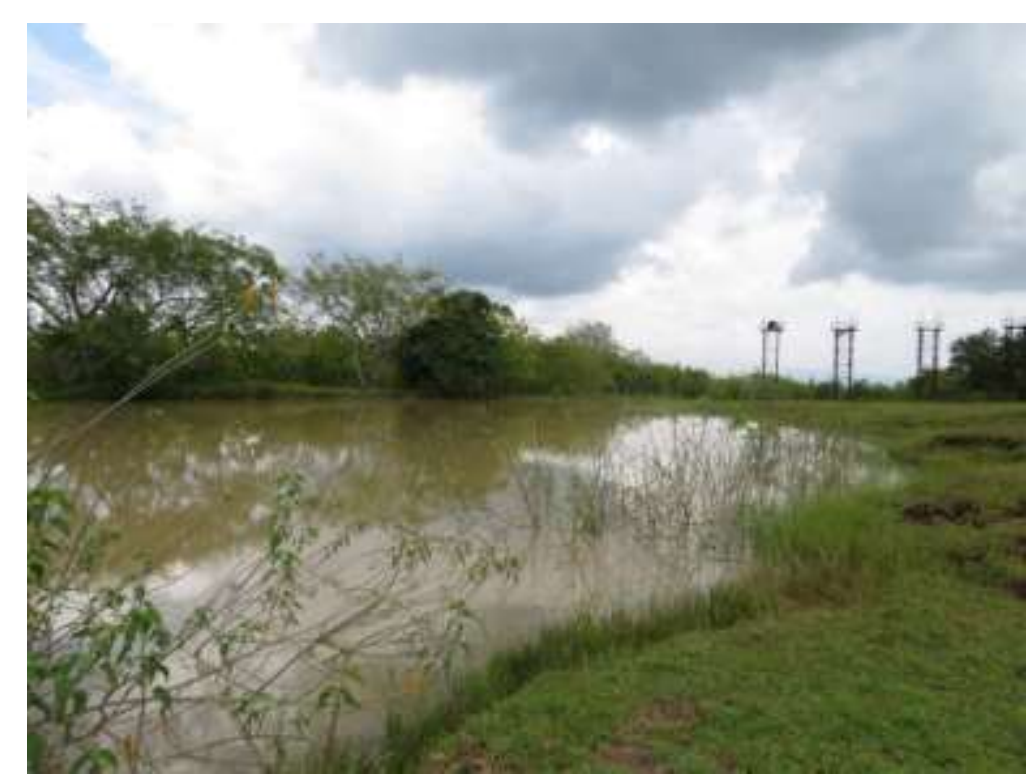

(a)

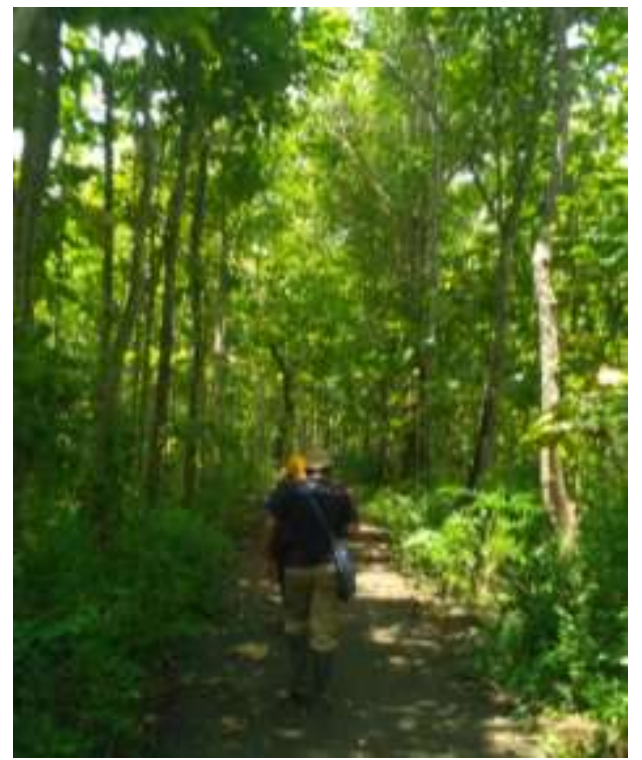

(b)

Gambar 3. Habitat kodok dan katak (Anura) di SM Paliyan (a) Petak 137 berupa danau dengan vegetasi riparian di satu sisi dan rerumputan di sisi seberangnya; dan (b) Petak 138 merupakan area hutan lebat dengan pepohonan tinggi dan kanopi rapat, tetapi tanpa genangan air.

Amfibi yang dijumpai di SM Paliyan cenderung mengumpul pada suatu titik tertentu (Gambar 4). Amfibi banyak dijumpai di area dengan adanya genangan air, baik kolam, sungai kecil dan telaga. Selain itu, mereka dijumpai diantara pepohonan dan semak yang lebat. Pada Petak 136, amfibi yang dijumpai berada disekitar sungai kecil dan tegalan. Pada Petak 137, amfibi yang dijumpai mengumpul, yakni berada di dalam dan sekitar Telaga Ringin. Sekitar 6 jenis amfibi ada di Telaga Ringin. Pada Petak 138, amfibi dijumpai di sekitar tegalan, genangan air kecil atau kolam dan bebatuan. Pada 
Petak 139, amfibi yang dijumpai mengumpul di sekitar telaga, terdapat sekitar 5 jenis berada di tepian dan sekitar telaga. Pada Petak 140 hanya dijumpai 1 jenis amfibi dan berada di sekitar genangan air. Pada Petak 141, dijumpai 3 jenis amfibi. Dua jenis dijumpai di tepian Telaga Guwoklepu yang mulai mengering dan satu jenis berada di batang kayu wilayah ladang.

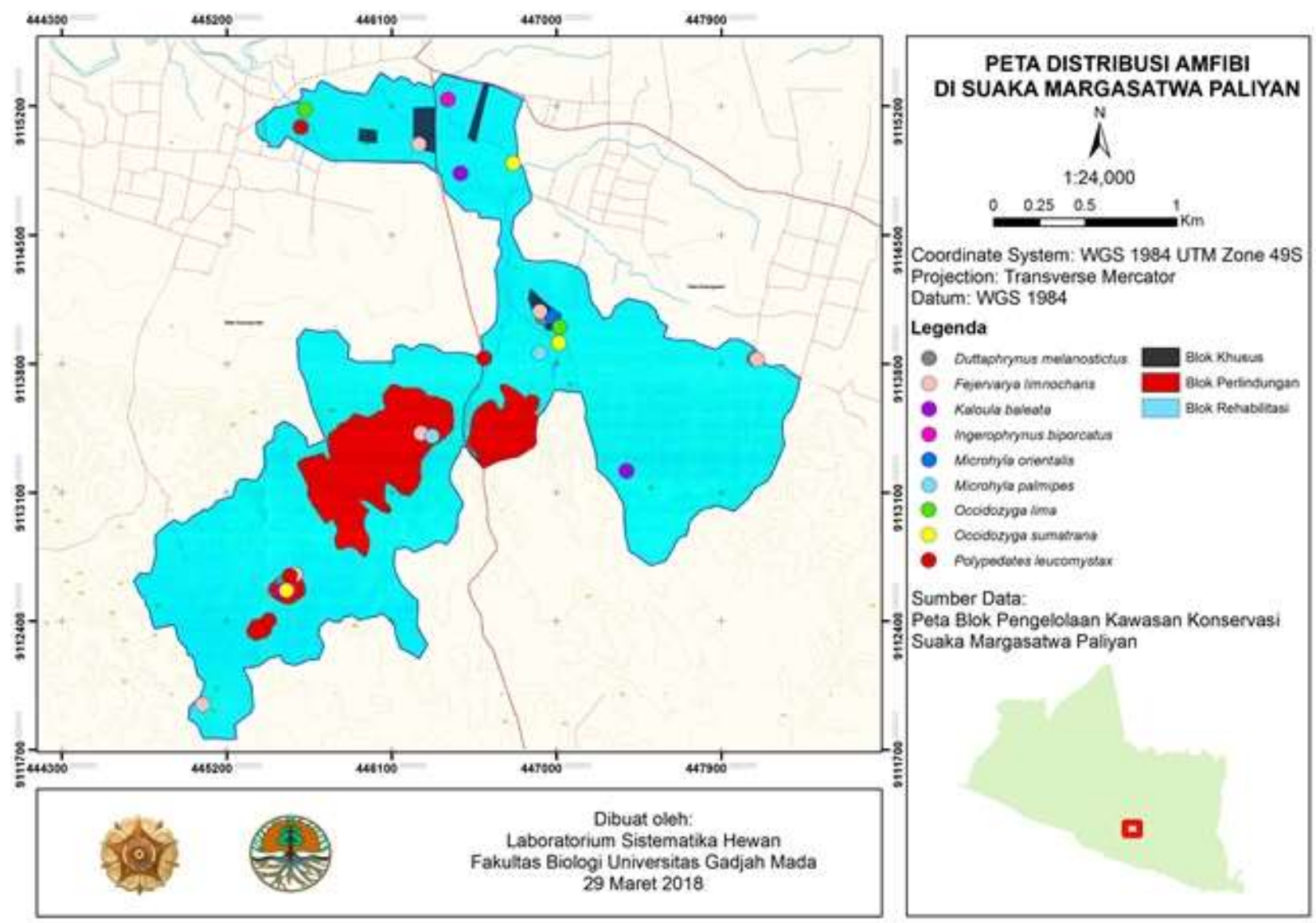

Gambar 4. Peta persebaran amfibi (katak dan kodok) di SM Paliyan tahun 2018.

\section{SIMPULAN}

Kawasan Suaka Margasatwa (SM) Paliyan merupakan habitat bagi 9 spesies katak dan kodok. Keanekaragaman katak dan kodok di SM Paliyan, berdasarkan Indeks Shanon-Wiener (H') dikategorikan "sedang". Nilai Indeks untuk katak dan kodok (anura) H': 1,43. Meskipun bukan habitat yang sempurna, wilayah SM Paliyan masih sesuai sebagai habitat katak dan kodok karena memiliki lokasi dengan hutan yang rindang, semak yang lebat, sungai-sungai dan telaga, serta area yang jarang dijadikan aktivitas manusia.

Perlu dilakukan penelitian mengenai keanekaragaman secara berkala (monitoring) untuk mengetahui dinamika keanekaragaman jenis katak dan kodok di kawasan SM Paliyan.

\section{UCAPAN TERIMA KASIH}

Terima kasih disampaikan kepada Kepala Balai Konservasi Sumber Daya Alam (BKSDA) Yogyakarta atas ijin penelitian. Teman-teman Polisi Hutan dan Pengendali Ekosistem Hutan di Suaka Margasatwa Paliyan yang telah membantu pengambilan data, serta Fakultas Biologi UGM yang telah melakukan Perjanjian Kerja Sama dengan BKSDA Yogyakarta. 


\section{KEPUSTAKAAN}

BKSDA. 2012. Suaka margastawa paliyan. http://www.bksdadiy.dephut.go.id/. Diakses pada tanggal 13 Februari 2016.

Bibi, F., and Z. Ali. 2013. Measurement of Diversity Indices of Avian Communities at Taunsa Barrage Wildlife Sanctuary Pakistan. The Journal of Animal \& Plant Sciences 23(2): 469-474.

Crump, L. Martha and N.J. Scott Jr. 1994. Visual Encounter Surveys in Measuring dan Monitoring Biological Diversity Standard Methods for Amphibians. Smithsonian Institution Press. Washington. Pp. 84.

Eprilurahman, R dan K. I. Kusuma. 2011. Amfibi dan Reptil di Lereng Selatan Gunung Api Merapi Sebelum Erupsi 2010. Jurnal Berkala Ilmiah Biologi 10 (1): 1-8.

Goin, C.J., O.B Goin, and G. R. Zug. 1978. Introduction to Herpetology. W.H. Freeman and Co. San Fransisco.

Heyer, W.R., M.A. Donnelly, R.W. MacDiarmid, L.C. Hayek and M.S. Foster. 1994. Measuring and Monitoring Biological Diversity: Standard Methods for Amphibians. Smithsonian Institution Press, Washington, DC. Pp. 364.

Ismawan, A., S.E. Rahayu, dan A. Dharmawan. 2015. Kelimpahan dan Keanekaragaman Burung di Prevab Taman Nasional Kutai Kalimantan Timur. Vol. 1, No. 1. Ilmu Hayati Universitas Negeri Malang.

Iskandar, D.T., 1998. Amfibi Jawa dan Bali: Seri Panduan Lapangan. Cetakan pertama, Puslitbang Biologi-LIPI, Bogor. Hal : 1 - 7 .

Jaeger, R.G. 1994. Patch sampling. In: Heyer, W.R., M.A. Donnelly, R.W. MacDiarmid, L.C. Hayek \& M.S. Foster (Eds). Measuring and Monitoring Biological Diversity: Standard Methods for Amphibians. Smithsonian Institution Press, Washington DC. Pp. 107-109.

Jaeger, R.G. and R.F. Inger. 1994. Quadrat sampling. In: Heyer, W.R., M.A. Donnelly,
R.W. MacDiarmid, L.C. Hayek \& M.S. Foster. (Eds). Measuring and Monitoring Biological Diversity: Standard Methods for Amphibians.. Smithsonian Institution Press, Washington DC. Pp. 97-102.

Karns, D.R. 1986. Field Herpetology, Methods for the Study of Amphibians \& Reptiles in Minnesota. James Ford Bell, Museum of Natural History, University of Minnesota. Occasional Paper: 18: 37-38.

Kurniati, H. 2003. Amphibians and Reptiles of Gunung Halimun National Park, West Java, Indonesia. Research Center for Biology - LIPI and Nagao Natural Environment Foundation NEF.

Kusrini, M. D. 2009. Pedoman Penelitian dan Survei Amfibi di Alam. Fakultas Kehutanan IPB. Bogor, Indonesia.

Pough, F.H., R.M. Andrew, J.E. Cadle, M.L. Crump, A.H. Savitzky, and K.D. Wells. 1998. Herpetology. Prentice-Hall, Inc. Upper Saddle River, New Jersey. Pp : 138, 169.

Ramadhani, A.F., 2015. Inventarisasi Amfibi Pada Musim Kemarau di Suaka Margasatwa Paliyan, Gunung Kidul, D.I. Yogyakarta. Laporan Kerja Praktek. Sarjana Strata Satu, Fakultas Biologi UGM.

Suprapto. 2014. Indeks Keanekaragaman Jenis Ikan Demersal di Perairan Tarakan. BAWAL Vol. 6(1): 47-53.

Türkmen, G., and N. Kazanci. 2010. Applications of various biodiversity indices to benthic macroinvertebrate assemblages in streams of a national park in Turkey. Review of Hydrobiology 3(2): 111-125.

Van Kampen, Dr. P.N., 1923. The Amphibia of the Indo-Australian Archipelago. E. J. Brill Ltd.

Yudha, D. S., R. Eprilurahman, K. Andryani dan Trijoko. 2013. Keanekaragaman Jenis Katak dan Kodok di Sungai Code Propinsi Daerah Istimewa Yogyakarta. Berkala Ilmiah Biologi 12(1):17-25. 
Yudha, D. S., R. Eprilurahman, Trijoko, M.F. Alawi, dan A.A. Tarekat. 2014. Keanekaragaman Jenis Katak dan Kodok (ordo Anura) di Sepanjang Sungai Opak Propinsi Daerah Istimewa Yogyakarta. Jurnal Biologi. 18 (2): 52-59.

Zug, G.R. 1993. Herpetology: An Introductory Biology of Amfibians and Reptiles. Academic Press, Inc. San Diego, California. 